University of Wollongong

Research Online

Faculty of Engineering and Information

Faculty of Engineering and Information

Sciences - Papers: Part A

Sciences

January 2014

\title{
Simulation of fully grouted rockbolts in underground roadways using FLAC2D
}

Shuqi Ma

University of Wollongong,sm426@uowmail.edu.au

Jan Nemcik

University of Wollongong, jnemcik@uow.edu.au

Naj Aziz

University of Wollongong, naj@uow.edu.au

Follow this and additional works at: https://ro.uow.edu.au/eispapers

Research Online is the open access institutional repository for the University of Wollongong. For further information contact the UOW Library: research-pubs@uow.edu.au 


\title{
Simulation of fully grouted rockbolts in underground roadways using FLAC2D
}

\author{
Abstract \\ A numerical modelling approach of a mine roadway reinforced with fully encapsulated rockbolts is \\ proposed to study the interaction between rockbolts and the rock mass. The rockbolt bond-slip \\ relationships defined by conducting push tests of short rockbolts are implemented in the rockbolt \\ elements used in the two-dimensional Fast Lagrangian Analysis of Continua (FLAC2D) model for precise \\ simulation of the rockbolt behaviour. The performance of rockbolts installed in the roadway model under \\ various conditions is discussed and compared with previous research. This paper provides a numerical \\ modelling methodology to study the interaction between rockbolts and the rock mass subject to a \\ variable stress state, rock mass quality, and the presence of rock fractures or joints. It was found that the \\ bearing plates can improve the reinforcing performance of rockbolts. Copyright 2014 Published by NRC \\ Research Press

\section{Keywords} \\ roadways, underground, rockbolts, grouted, fully, flac2d, simulation \\ Publication Details \\ Ma, S., Nemcik, J. \& Aziz, N. (2014). Simulation of fully grouted rockbolts in underground roadways using \\ FLAC2D. Canadian Geotechnical Journal, 51 (8), 911-920.
}




\title{
Simulation of fully grouted rockbolts in underground roadways
}

\author{
using FLAC2D \\ Shuqi Ma, Jan Nemcik ${ }^{*}$, Naj Aziz \\ School of Civil, Mining and Environmental Engineering, University of Wollongong, NSW
}

2522, Australia

\begin{abstract}
:
A numerical modelling approach of a mine roadway reinforced with fully encapsulated rockbolts is proposed to study the interaction between the rockbolts and the rock mass. The rockbolt bond-slip relationships defined by conducting push tests of short rockbolts are implemented in the rockbolt elements used in the two-dimensional Fast Lagrangian Analysis of Continua (FLAC2D) model for precise simulation of the rockbolt behaviour. The performance of rockbolts installed in the roadway model under various conditions was discussed and compared with the previous research. This paper provides a numerical modelling methodology to study the interaction between rockbolts and rock mass subject to variable stress state, rock mass quality and the presence of rock fractures or joints. It was found that the bearing plates can improve the reinforcing performance of rockbolts.
\end{abstract}

Keywords: FLAC model; Rockbolt elements; Fully grouted rock bolts; Push tests; Underground roadway.

\section{Introduction}

Rockbolts are used as primary reinforcement to strengthen the jointed/fractured rock mass in civil and mining engineering excavations. Windsor (1997) categorised the current reinforcement devices into three fundamental classes: Continuous Mechanically Coupled

\footnotetext{
* Corresponding author: Tel.: +61 242214492

E-mail address: jnemcik@uow.edu.au
} 
(CMC), Continuous Frictionally Coupled (CFC) and Discretely Mechanically or Frictionally Coupled (DMFC). The fully encapsulated rockbolt system belongs to CMC, while expansion shell bolts belong to the DMFC system and the Swellex and Split set rockbolts to the CFC system. Because of the simple installation procedure, effective rock reinforcement and economic factors, cement or resin grouted rockbolts are the most commonly used ground reinforcement method.

The primary role of rockbolts is to restrain the rock mass deformation by providing resistance to dilation and shear movement. This research is focused on the axial rockbolt behaviour only. Cai (2004) indicated that the axial force distribution along a rockbolt has a significant supporting effect and plays an important role in the design of the rockbolt pattern. Björnfot and Stephansson (1984) indicated that rock mass quality can significantly influence the behaviour of fully grouted rockbolts. The bond characteristics of the rockbolts are influenced by the surrounding rock, the types of rockbolts and grout. Better understanding of the load transfer mechanism between rockbolts and rock mass can lead to improved design of the rockbolting system in the field. So far the rockbolt system design for underground roadways in complex ground environments remains primarily empirical. Considering the difficulty and cost of field monitoring, analytical and numerical models can provide alternative ways to study the bolt loading behaviour.

A series of analytical solutions (Farmer, 1975; Li and Stillborg, 1999; Ren et al., 2010; Blanco Martín et al., 2011; Ma et al., 2013) have been made to study the load transfer mechanism in the rockbolting system. Farmer (1975) presented an analytical model to predict the shear stress distribution of fully grouted rockbolts before decoupling occurs in the boltgrout interface. Li and Stillborg (1999) proposed a model for describing the behaviour of rockbolts by dividing the rockbolt into elastic, softening and de-bonding zones. Ren et al. (2010) and Blanco Martín et al. (2011) presented analytical models for fully grouted 
rockbolts based on a tri-linear bond-slip model. Ma et al. (2013) introduced a non-linear bond-slip model to analytically simulate the behaviour of fully grouted rockbolts. However, these analytical models have difficulty in representing the true interaction between rockbolts and the in situ rock mass as the solutions are based on simplified bolt-collar loading experiments.

Indraratna and Kaiser (1990) presented an analytical method to model the behaviour of a circular tunnel supported by fully grouted rockbolts and Osgoui (2010) improved this model to obey the non-linear Hoek-Brown yield criterion rather than the Mohr-Coulomb linear failure criterion. The limitations of the analytical models by Indraratna and Kaiser (1990) and Osgoui (2010) are:

a) Bearing plates were not taken into account.

b) The bolts were assumed as rigid meaning that any point along the rockbolt experiences the same displacement.

c) The shear bond stress was not defined in appropriate way. To model the interfacial shear stress distribution of the fully grouted rockbolt, the rockbolt was mechanically divided into a pick-up length and an anchor length, on either side of the neutral point. The neutral point position was determined by an empirical equation.

d) These analytical models were proposed for a circular tunnel and therefore may not be easily applied to rectangular roadways due to a different stress distribution.

Hyett (1996) encouraged the use of numerical packages in reinforcement design if these numerical methods are capable of simulating the fully grouted rockbolts. FLAC2D is established on explicit finite difference formulation and supplies structural elements representing the soil and rock support system. FLAC have seven specified types of structural support elements: beam elements, liner elements, cable elements, pile elements, rockbolt 
elements, strip elements and support members. Rockbolt elements were selected in this study due to their capability of modelling the strain-softening behaviour of the material between the structural elements and the grid (Itasca, 2006). Although FLAC2D is a two dimension model, it can still accurately represent the three-dimensional effect of the rockbolt interaction with rock. Rockbolt elements are two-dimensional and interact with the FLAC grid through coupling springs, which are nonlinear connectors that transfer forces and motion between the rock bolt elements and the grid at the rockbolt element nodes.

Although rockbolt elements or the cable bolt elements provided by FLAC software are popular in modelling the rockbolts in the field (Gale et al., 2004; Mark et al., 2007; Liu et al., 2008; Hsiao et al., 2009), they cannot feature the interfacial shear bond softening mechanism between the bolt and the rock mass when used without being modified. According to the study of Ren et al. (2010); Blanco Martín et al. (2011) and Ma et al. (2013) the shear bond stress between the rockbolt element and the grid/rock mass varies nonlinearly with the relative displacement between the rockbolt node and the FLAC grid as shown in Fig. 5. Hence, the FLAC code requires modifications in order to allow for adjusting the interfacial shear bond stress along the bolt as a function of relative shear displacement. The behaviour of fully encapsulated rockbolts as normally installed in underground coal mine roadways was modelled using the FLAC2D rockbolt element that was modified by incorporating the FISH (a programming language embedded within FLAC) to enable a non-linear bondslip relationship that was derived experimentally. The effect of face plates, rock mass quality and the occurrence of the rock joint was taken into consideration. Once the underground roadway geology, stress state and rockbolt bond characteristics are known, the model can be used to study the behaviour of mine roadways. 
To obtain the bond-slip relationship along the bolt-grout interface, a series of push tests were conducted and the results implemented in the FLAC model to simulate the rock bolts in underground roadways.

\section{Laboratory push tests of short encapsulated rock bolts}

The load transfer capacity of fully encapsulated resin-grouted rockbolts is influenced by resin types and installation methods. A series of push tests were carried out at the University of Wollongong (UOW) to study the bond characteristics. Owing to the difficulty of installing a roof bolt at a mining face and then removing the bolt for testing in a laboratory, steel tubes were introduced to provide a suitable substitute.

Several rockbolts were installed into steel tubes using a standard bolt installation procedure for fully encapsulated rock bolts. The steel tubes were $1.7 \mathrm{~m}$ long with an internal diameter of $28.5 \mathrm{~mm}$ and a wall thickness of $9 \mathrm{~mm}$. One end of the steel tubes was welded to a square steel base plate while the other end was closed with the cap. The steel tubes were installed vertically into a $64 \mathrm{~mm}$ diameter hole drilled into the mine roof, then removed and brought to the laboratory for testing. The tubes with the installed bolts are as shown in Fig.1.

The installed rock bolts were cut into 15 sections, each $100 \mathrm{~mm}$ in length and numbered as illustrated in Fig.2. The outer $200 \mathrm{~mm}$ long section near the collar of the hole was not fully encapsulated because of the lack of resin. The load transfer of the individual $100 \mathrm{~mm}$ long bolt sections was tested by pushing the bolt out of the tube using the Instron universal test machine. The test setup is shown in Fig.3. During the push test, the loading force and the displacement were recorded for each tube section. The load and displacement relationships of the bolt 10 are shown in Fig.4.

Each tube section along the rockbolt had a distinct load-displacement curve, indicating that in reality the shear bond capacity is not constant along the bolt. This was caused by several factors including capsule film gloving, entrapped air bubbles and resin mix times. Additional 
results were reported by Hillyer et al. (2013). Since the rockbolts were installed following the standard procedure, the experiments closely represent the practical behaviour of the rockbolts in the field. However, past laboratory experiments showed that the short encapsulation rockbolt push tests were approximately 25\% higher than the pull tests (Aydan, 1989). Aziz (2004) reported a $10 \%$ difference of the load bearing capacity in push and pull tests. In this study the rockbolt push tests were implemented as the pull tests would have been impractical due to the bolt specimen length.

Benmokrane et al. (1995) and Blanco Martín et al. (2011) proposed that grouted rockbolts in short encapsulation could be employed to derive the relationship of the interface between the rockbolt and the medium as long as the embedment length was short enough to ensure a uniform distribution of shear stress. The shear stress distributes uniformly along the $100 \mathrm{~mm}$ long section and hence the load-displacement curves can be treated as the fundamental relationship for the rockbolt-grout interface.

The obtained load-displacement relationships can be converted to bond stress versus slip relationships and the bond strength $(\tau)$ of one section can be calculated using the following equation (Littlejohn and Bruce, 1975):

$\tau=\frac{P}{\pi d_{b} L}$

where $L$ is the encapsulated length; $d_{b}$ is the diameter of rockbolt; $P$ denotes the push load on the loaded bolt end.

Bolt 10 shown in Fig. 1 was selected as an example and used in the following study. Bondslip curves were implemented into the FLAC model and the bolt behaviour was modelled under various situations. Three representative bond-slip curves (section $\mathrm{K}, \mathrm{L}$ and $\mathrm{N}$ ) derived from push tests are illustrated in Fig. 5. 


\section{Introduction of rockbolt elements in FLAC2D}

Rockbolt elements in FLAC2D were introduced by Ma et al. (2013) to simulate non-linear behaviour of rockbolts due to their capacity of modelling the strain-softening behaviour of the material between the structural element and the grid material (Itasca, 2006).

The shear behaviour of the rockbolt/grid interface is modelled by a spring-slider system at the rockbolt nodal points. The interfacial shear behaviour during the relative displacement between the structural rockbolt nodes and the grid is a function of the coupling spring shear stiffness (cs_sstiff shown in Fig. 6b) (Itasca, 2006):

$$
\frac{F_{S}}{L}=c S_{s s t i f f}\left(u_{p}-u_{m}\right)
$$

where: $F_{S}$ denotes the shear force that develops in the shear coupling spring; $c s_{\text {sstiff }}$ is the coupling spring shear stiffness (in FLAC: cs_sstiff); $u_{p}$ refers to the axial displacement of the rockbolt; $u_{m}$ is the axial displacement of the medium (soil or rock); $L$ is the contributing element length.

The maximum shear force is correlated to the cohesive strength of the interface and the frictional resistance along the interface. The maximum shear force per length of the rockbolt can be calculated as follows:

$$
\frac{F_{S}^{\max }}{L}=c S_{\text {scoh }}+\sigma_{C}^{\prime} \times \tan \left(c S_{\text {sfric }}\right) \times \text { perimeter }
$$

where: $c s_{\text {scoh }}=$ cohesive strength of the shear coupling spring (in FLAC: cs_scoh); $\sigma_{C}^{\prime}=$ mean effective confining stress normal to the rockbolt element; $c s_{\text {sfric }}=$ friction angle of the shear coupling spring (in FLAC: cs_sfric); perimeter = exposed perimeter of the element.

The shear force per rockbolt length, namely cs_scoh in FLAC, can be correlated to the relative shear displacement. User-defined table cs_sctable links the shear coupling-spring 
cohesion (cs_scoh) to the relative shear displacement. Hence, the shear bond along the rockbolt element can be described as a function of shear displacement using cs_sftable, providing a way of adding an existing bond-slip curve in a FLAC model. In this paper, the shear force in Eq. (3) is a function of cs_scoh, which is independent of the friction angle properties (cs_sfric) and cs_sfric were hence set to zero.

The bond-slip was then implemented into the rockbolt element by cs_sctable, defining the relationship between shear force divided by the contributing element length and displacement. According to the definition, cs_scoh is the cohesive strength of the shear coupling spring (with the unit of force/rockbolt length), which can be expressed as:

$c s_{-} \operatorname{scoh}=\pi d_{b} \tau$

and hence, shear stress $\tau$ can be computed as follows:

$$
\tau=\frac{c s_{-} s c o h}{\pi d_{b}}
$$

where $d_{b}$ is the diameter of rockbolt; $\tau$ denotes the shear stress along the rockbolt.

Therefore, bond-slip curves of $100 \mathrm{~mm}$ sections of rockbolt 10 were transferred into the relationships of shear force per length versus displacement by Eq. (4a).

\section{FLAC simulation of rockbolts}

A numerical pull out test was conducted on the FLAC rockbolt model. The diameter of the rockbolt was $22 \mathrm{~mm}$ while Young's modulus of rockbolt steel and the tensile strength were $210 \mathrm{GPa}$ and $335 \mathrm{kN}$ respectively. The rockbolt properties used are shown in Table 1.

Table 1 Rockbolt properties used in FLAC model

\begin{tabular}{|c|c|c|c|c|}
\hline $\begin{array}{c}\text { Cross- } \\
\text { sectional area } \\
\left(\mathrm{m}^{2}\right)\end{array}$ & $\begin{array}{c}\text { Elastic } \\
\text { modulus } \\
(\mathrm{Pa})\end{array}$ & $\begin{array}{c}\text { Perimeter } \\
(\mathrm{m})\end{array}$ & $\begin{array}{c}\text { cs_sstiff } \\
(\mathrm{N} / \mathrm{m} / \mathrm{m})\end{array}$ & $\begin{array}{c}\text { Tensile yield } \\
\text { strength } \\
(\mathrm{N})\end{array}$ \\
\hline $3.8 \mathrm{E}-04$ & $2.10 \mathrm{E}+11$ & 0.069 & $5.00 \mathrm{E}+9$ & $3.35 \mathrm{E}+5$ \\
\hline
\end{tabular}


To simulate one rockbolt (say rockbolt No.10), the FLAC model of the rockbolt consisted of 17 elements, which is schematically shown in Fig. 7. Rockbolt elements 1 to 17 represent the sections of A to Q shown in Fig.2. Each rockbolt element was assigned its corresponding distinct bond-slip relationship by the user-defined table cs_sctable. Based on the previous discussions, zero bond characteristics were input into the two rockbolt elements close to the hole collar (namely rockbolt elements 16 and 17 shown in Fig.7). The pull-out velocity of 1e$6 \mathrm{~m} / \mathrm{step}$ was applied at the end of the bolt (node 18). All FLAC model grid points were fixed in both the $x$ and $y$ directions.

\subsection{Evaluation of the FLAC2D model}

The coupling spring shear force and shear displacement of rockbolt elements 11,12 and 14 (corresponding to section $\mathrm{K}, \mathrm{L}$ and $\mathrm{N}$ in Fig. 2) were monitored and compared with the input bond-slip relationships. Because of the long encapsulation, the tensile strength of the rockbolt was set to a large value of $3.35 \times 10^{9} \mathrm{~N}$ to ensure adequate displacement for each section and to prevent the yield of the rockbolt in the test. The obtained value of the shear force was transferred to shear stress by Eq. (4b). The comparison of the calculated and the input bond slip curves for these three rockbolt elements are shown in Fig. 8. As can be seen in Fig. 8, the FLAC model agrees well with the input bond-slip experimental relationships. The FLAC model can successfully represent the local non-linear behaviour of rockbolts, which is capable of simulating the reaction of rockbolts under different situations.

\subsection{Rockbolt pull-out test}

A tensile strength value of $335 \mathrm{kN}$ was assigned to rock bolt 10 , which was pull tested until failure. The load-displacement was recorded and shown in Fig. 9. The bolt reached its tensile strength of $320 \mathrm{kN}$. During pull testing the loaded end moved approximately $2.5 \mathrm{~mm}$. The axial force and shear force distribution in the FLAC model are illustrated respectively in Fig. 
10 and Fig. 11. It can be seen that the axial force was mobilised only in the section close to the collar. As shown in Fig. 11 the shear force along the bolt-rock interface at the rockbolt elements 16 and 17 is zero as this portion of the bolt was not encapsulated.

\section{Simulation of the interaction between rockbolt and rock mass}

In underground mines, once the roadway is excavated, the surrounding rock mass will potentially move towards the roadway, causing roadway closure (roof lowering, floor heave and lateral rib closure). The installation of rockbolts aims to improve the inherent selfsupporting rock strength. The axial force in the bolt and the interfacial shear stress along the bolt depends on the rock mass deformation. After being installed, rockbolts work together with the reinforced rock mass (Deb, 2006) and provide a resistance to rock mass deformation. Because of the roadway opening, the rock mass close to the excavation is displaced more than the interior rock mass. Rockbolts play a role in force being transmitted from the exterior rock to the interior, which is done via the shear stresses at the rockbolt-grout interface (Sun, 1984). Based on in situ observations, Sun (1984) proposed that the deformation of the rock mass eventually leads to three distinct zones developed along a rockbolt; neutral point, pickup length and anchor length. The relative displacement between the rock and the bolt is zero at the neutral point, where the shear bond stress at the bolt-grout interface is zero while the axial force reaches the maximum value. The section between the collar and the neutral point is defined as the load pick-up part (Indraratna and Kaiser, 1990; Li and Stillborg, 1999) while the length between the neutral point and the free end of the rockbolt forms the anchoring part.

In the simulation, the non-linear Hoek-Brown failure criterion is employed to model the surrounding rock mass of the roadway in an underground mine. The Hoek-Brown criterion is an empirical strength relationship, having the capacity of describing a non-linear increase in strength of rock with increasing confining pressures. After several years of improvement, the 
latest version of the failure criterion (Hoek et al., 2002) provides an effective method to predict rock mass properties based on laboratory measurements and field observations. Eberhardt (2012) recommended that the Hoek-Brown criterion can be used for most rock types (igneous, sedimentary and metamorphic) under various confinements.

The latest expression of the Hoek-Brown criterion (Hoek et al., 2002) is:

$\sigma_{1}^{\prime}=\sigma_{3}^{\prime}+\sigma_{c i}\left(m_{b} \frac{\sigma_{3}^{\prime}}{\sigma_{c i}}+s\right)^{a}$

where: $\sigma_{1}^{\prime}$ and $\sigma_{3}^{\prime}$ are the major and minor effective principal stresses at failure; $\sigma_{c i}$ is the uniaxial compressive strength of the intact rock material.

The parameters $m_{b}, s$ and $a$ in Eq. (5) are semi-empirical, which are related to Geological Strength Index (GSI). GSI can be estimated directly from charts based on the overall rock mass structure and the surface conditions of the discontinuities.

The coefficients $m_{b}, s$ and $a$ are the function of GSI described by:

$$
\begin{aligned}
& m_{b}=m_{i} \exp \left(\frac{G S I-100}{28-14 D}\right) \\
& s=\exp \left(\frac{G S I-100}{9-3 D}\right) \\
& a=\frac{1}{2}+\frac{1}{6}\left(e^{-G S I / 15}-e^{-20 / 3}\right)
\end{aligned}
$$

In Eq. (6) and Eq. (7), a factor $D$ is introduced to describe the degree of disturbance caused by blast damage and stress relaxation.

When rock mass surrounding the excavation reaches its residual (post-peak) strength, the Hoek-Brown failure criterion can be expressed as:

$$
\sigma_{1}^{\prime}=\sigma_{3}^{\prime}+\sigma_{c i}^{\prime}\left(m_{b}^{\prime} \frac{\sigma_{3}^{\prime}}{\sigma_{c i}^{\prime}}+s^{\prime}\right)^{a^{\prime}}
$$


Parameters $m_{b}^{\prime}, s^{\prime}, a^{\prime}$ are the residual strength of $m_{b}, s, a$ and $\sigma_{c i}^{\prime}$ is the residual uniaxial compressive strength of the intact rock $\sigma_{c i}$.

An attempt has been made to study the interaction mechanism between rockbolts and rock mass which were simulated by rockbolt elements in FLAC and the Hoek-Brown material, respectively.

The numerical model geometry and the applied boundary conditions of a roadway are presented in Fig. 12. Because of the model symmetry only half of the roadway was simulated. The FLAC grid size representing strata in the region of interest was $50 \mathrm{~mm}$ by $50 \mathrm{~mm}$ and the simulated roadway dimensions were $5.5 \mathrm{~m}$ by $2.5 \mathrm{~m}$. The FLAC rockbolt model proposed here was adopted. The fully grouted rockbolts were labelled as shown in Fig. 12.

The Hoek-Brown constitutive model in FLAC was used. Two types of rock mass (GSI=35 and GSI=50) were adopted, where GSI=35 indicates rock mass "folded and/or faulted with angular blocks formed by many intersecting discontinuity sets" and GSI=50 represents “interlocked, partially disturbed rock mass with multifaceted angular blocks formed by four or more discontinuity sets" (Hoek et al., 2002). The constant $m_{i}$ was set as 10 and 12 for rock mass $\mathrm{GSI}=35$ and $\mathrm{GSI}=50$, respectively. Table 2 illustrates the material parameters adopted from Osgoui (2010) and used in the FLAC roadway model. The densities of these two different types of rock mass were considered the same and set as $2000 \mathrm{~kg} / \mathrm{m}^{3}$. Rockbolt behaviour under various conditions (four models) was simulated and is detailed in Table 3. In the Model 4, a horizontal joint was created in the roof to model the discontinuous rock mass.

Table 2. Geomechanical parameters of rock mass used in FLAC model, after Osgoui (2010).

\begin{tabular}{|l|r|r|}
\hline Parameter & GSI=35 & GSI $=50$ \\
\hline Poisson's ratio & 0.25 & 0.25 \\
\hline Deformation Modulus E $(\mathrm{GPa})$ & 2.57 & 9.34 \\
\hline Shear Modulus G $(\mathrm{Gpa})$ & 1.028 & 3.736 \\
\hline Intact rock strength $\sigma_{c i}(\mathrm{MPa})$ & 30 & 60 \\
\hline
\end{tabular}




\begin{tabular}{|l|r|r|}
\hline Residual intact rock strength $\sigma_{c i}^{\prime}(\mathrm{MPa})$ & 24 & 48 \\
\hline Disturbance Factor D & 0 & 0 \\
\hline Hoek-Brown constant $m_{i}$ & 10 & 12 \\
\hline Hoek-Brown constant $m_{b}$ & 0.981 & 2.012 \\
\hline Hoek-Brown constant $m_{b}^{\prime}$ & 0.615 & 0.841 \\
\hline Hoek-Brown constant $s$ & $7.30 \mathrm{E}-04$ & $3.87 \mathrm{E}-03$ \\
\hline Hoek-Brown constant $s^{\prime}$ & $1.70 \mathrm{E}-04$ & $2.57 \mathrm{E}-04$ \\
\hline Hoek-Brown constant $a$ & 0.516 & 0.505 \\
\hline Hoek-Brown constant $a^{\prime}$ & 0.538 & 0.530 \\
\hline
\end{tabular}

Table 3. Variable conditions used in FLAC model

\begin{tabular}{|l|c|c|c|c|c|c|c|c|}
\hline $\begin{array}{c}\text { FLAC } \\
\text { Model } \\
\text { Parameters }\end{array}$ & $\begin{array}{c}\sigma_{x x} \\
(\mathrm{MPa})\end{array}$ & $\begin{array}{c}\sigma_{y y} \\
(\mathrm{MPa})\end{array}$ & $\begin{array}{c}\sigma_{z z} \\
(\mathrm{MPa})\end{array}$ & $\begin{array}{c}\mathrm{P}_{0} \\
(\mathrm{MPa})\end{array}$ & $\begin{array}{c}\mathrm{P}_{1} \\
(\mathrm{MPa})\end{array}$ & $\begin{array}{c}\text { Rock } \\
\text { mass } \\
\text { GSI }\end{array}$ & $\begin{array}{c}\text { Face } \\
\text { plate }\end{array}$ & Joint \\
\hline Model 1 & -6 & -4 & -5 & -4 & -6 & 35 & No & No \\
\hline Model 2 & -6 & -4 & -5 & -4 & -6 & 50 & No & No \\
\hline Model 3 & -6 & -4 & -5 & -4 & -6 & 50 & Yes & No \\
\hline Model 4 & -6 & -4 & -5 & -4 & -6 & 50 & Yes & Yes \\
\hline
\end{tabular}

\subsection{Model 1-Roadway with GSI=35}

In this model, stress tensor $\sigma_{x x}=-6 \mathrm{MPa}, \sigma_{y y}=-4 \mathrm{MPa}$ and $\sigma_{z z}=-5 \mathrm{MPa}$ was initialised throughout the model grid and the boundary stress $\mathrm{P}_{0}=-4 \mathrm{MPa}$ and $\mathrm{P}_{1}=-6 \mathrm{MPa}$ (Fig. 12) and rock mass with GSI=35 was adopted. Rock bolts were installed after the roadway was excavated. The results are illustrated in Fig. 13. Rockbolt 2 in Fig. 13 has a distinctive behaviour because it yielded during the modelling. The axial force distribution along rockbolt 1 is shown in Fig. 14, which is comparable to the measurements obtained by Gale, et al. (1992), as shown in Fig. 15. As can be seen, all three rockbolts developed the neutral point, the pick-up length and anchoring length; the direction of shear stress for the anchor length and the pick-up length is opposite, which confirms the field observations of Sun (1984).

Rockbolts 1 and 3 have different axial force and shear force distribution as well as the different neutral position. It can be concluded that the neutral position depends on the spot 
where the rockbolt is installed, implying that rockbolt behaviour is influenced by the surrounding stress conditions.

\subsection{Model 2-Roadway with GSI=50}

In Model 2, rock mass was set to $\mathrm{GSI}=50$ and all other settings were kept the same as in Model 1. The only difference between Model 1 and Model 2 is the rock mass quality, the objective of which is to study the influence of the rock mass properties on the behaviour of the rockbolt. Fig. 16 shows the results of Model 2. Rockbolt 1 in Model 2 was chosen as a representative to compare with the rockbolt 1 in Model 1 and its shear force and axial force distribution is shown in Fig. 17. It can be seen that the shear and axial forces distribute in different ways along the bolts between Model 1 and Model 2. For the rockbolts in Model 2, a large neutral section exists instead of a single point indicating that rockbolts displace together with the surrounding rock mass along these sections. The discrepancy of neutral point locations between Model 1 and Model 2 agrees with the rock mass characteristics affecting the rockbolt behaviour (Cai et al., 2004).

\subsection{Model 3-The effect of bearing plates}

Gray (1998) stated that bearing plates "prevent the nut or forged head at the end of the rockbolt from being pulled into the rockbolt hole”. Nitzsche and Haas (1976) proposed that the application of bearing plates will help strengthen the fractured rock mass near the collar. It is believed that the rockbolt with a plate behaves differently from the one without a plate. The purpose of Model 3 is to research the effect of bearing plates as Models 1 and 2 did not account for bearing plates. Bearing plates were simulated by increasing the load transfer between the last rockbolt element and the surrounding strata at the collar of the hole. Models 2 and 3 had the same rock mass properties and stress boundary conditions as detailed in Table 
3. The behaviour of rockbolts with plates (Model 3) was compared with the profiles of rockbolts without plates (Model 2) and shown in Fig. 18.

In Fig. 18, it is clear that rockbolts with bearing plates still have neutral points, and even under the same geological and stress conditions, rockbolts with plates tend to have higher axial load and shear load. Rockbolts with plates can restrain the deformation of rock more effectively resulting in higher axial force generated in the rockbolts. Face plates can also influence the neutral point location. As can be seen in Fig. 18, the rock bolts with and without plates have distinctive pick-up length, anchor length and neutral point positions. Rockbolts with plates experienced additional load and hence, the bolt pick-up length is calculated in order to establish the force equilibrium state.

In addition, the mine roadway in the Model 3 experienced smaller roof convergence than in the Model 2 as shown in Table 4, which further confirms that the bearing plates can increase the reinforcement effect of rockbolts.

Table 4 The Roof convergence of bolt 1 and 2 in Model 2 and 3

\begin{tabular}{|c|c|c|}
\hline Roof convergence $(\mathrm{mm})$ & Bolt 1 & Bolt 2 \\
\hline Model 2 & 6.84 & 7.37 \\
\hline Model 3 & 6.13 & 5.89 \\
\hline
\end{tabular}

\subsection{Model 4-Jointed roof}

Rock joints were simulated by placing an interface $0.8 \mathrm{~m}$ above the roof. The axial force and shear force distributions of the two roof bolts are shown in Fig. 19. As can be seen, the axial force reached the maximum value at the joint intersection, decreasing gradually away on either side. This was caused by the displacement and subsequent dilation along the joint. Because of the peak axial force generated within the rockbolt at the joint location, the bolts 
failed before the whole roadway model reached the force equilibrium state. Hence, the results shown in Fig. 19 were produced prior to rockbolt failure.

Hyett et al. (1996) stated that a higher reinforcement load would develop in discontinuous rock mass than in a continuous rock mass. Models 3 and 4 hold the same setting parameters except for the existence of the roof joint in Model 4. When Model 3 and 4 were both loaded at the same rate, the rockbolts in Model 3 were still intact but the axial forces in rockbolts reinforcing the joint (Model 4) have exceeded the bolt strength.

The modelling shows that delaying the installation of rockbolts after the roadway excavation can cause a lower axial force in bolts and hence prevent the damage to rock bolts; however, it would weaken the overall supporting performance of rockbolts. A similar conclusion was also proposed by Cai et al. (2004) based on an analytical model.

\section{Conclusions}

Rockbolts were modelled by the FLAC rockbolt elements by taking into account the bondslip relationship of the bolt-grout interface that was derived from the laboratory short encapsulation bolt push tests. The laboratory tests provide the practical solution to investigation of the rockbolt behaviour in contrast to the field pull-out tests that are often subjected to many variables.

Simulations of a mine roadway reinforced by the proposed rockbolt model were conducted to predict the behaviour of rockbolts, from which the derived conclusions are:

a) Due to the difference in deformation between the exterior rock mass and the interior rock mass, pick-up length and anchor length are formed along the rockbolts;

b) Rock mass quality can impact on the axial force and interfacial shear force distribution along the rockbolts as well as the position of the neutral point;

c) Bearing plates can improve the reinforcing performance of rockbolts; 
d) Peak axial stress can be developed at rock joints which can lead to the rupture of the rockbolts.

The factors such as the bond characteristics of rockbolt-grout interface, rock mass properties and in situ conditions, need to be carefully considered when bolting design is undertaken. The proposed FLAC model in this paper is capable of simulating the practical response of rockbolts in the field. To reach a realistic simulation of underground roadway reinforcement systems, the proposed numerical model should be built on the knowledge of the bond-slip relationship of the bolt-grout interface and the field monitoring data. These include the stress state around the roadway, rock mass quality, the occurrence of rock joints or faults and other related factors.

This paper provides engineers with valuable tools to understand the axial behaviour of the rockbolts reinforcing underground rock mass and to optimise the design of the rockbolt pattern.

\section{References:}

Aydan, O. 1989. The stabilisation of rock engineering structures by rock bolts. In Geotechnical Engineering. Nagoya University, Nagoya.

Aziz, N.I. 2004. An Update of Roof Bolt Research at the University of Wollongong. Coal 2004: Coal Operators' Conference. University of Wollongong \& the Australasian Institute of Mining and Metallurgy. pp. 215-224.

Benmokrane, B., Chennouf, A., and Mitri, H.S. 1995. Laboratory evaluation of cement-based grouts and grouted rock anchors. International Journal of Rock Mechanics and Mining Sciences and Geomechanics Abstracts 32(7): 633-642.

Bjönfot, F., and Stephanson, O. 1984. Interaction of grouted rock bolts and hard rock masses at variable loading in a test drift of the Kiirunavaara Mine, Sweden. International Symposium on Rock Bolting, A. A. Balkema. pp. pp. 337-395.

Blanco Martín, L., Tijani, M., and Hadj-Hassen, F. 2011. A new analytical solution to the mechanical behaviour of fully grouted rockbolts subjected to pull-out tests. Construction and Building Materials 25(2): 749-755.

Cai, Y., Esaki, T., and Jiang, Y. 2004. An analytical model to predict axial load in grouted rock bolt for soft rock tunnelling. Tunnelling and underground space technology 19(6): 607-618.

Deb, D. 2006. Finite Element Methods: Concepts and Applications in Geomechanics. PHI Learning Pvt. Ltd. pp. 298-303. 
Eberhardt, E. 2012. The Hoek-Brown Failure Criterion. Rock mechanics and rock engineering 45(6): 981-988.

Farmer, I.W. 1975. Stress distribution along a resin grouted rock anchor. Rock mechanics and mining science 12: 347-351.

Gale, W., Fabjanczyk, M.W., Tarrant, G.C., and Guy, R.J. 1992. Optimisation of reinforcement design of coal mine roadways. 11th International Ground Control in Mining. Edited by N. Aziz and S. Peng, Univeristy of Wollongong. pp. 272-279.

Gale, W., Mark, C., Oyler, D., and Chen, J. 2004. Computer simulation of ground behaviour and rock bolt interaction at Emerald Mine. 23rd: INTERNATIONAL CONFERENCE ON GROUND CONTROL IN MINING. pp. 27-34.

Gray, P. 1998. Bearing plates: new developments in the unsung heroes of ground support. Coal 1998: Coal Operators' Conference, University of Wollongong \& the Australasian Institute of Mining and Metallurgy,Australia. pp. 167-178.

Hillyer, J., Craig, P., Ma, S., Aziz, N.I., Nemcik, J., and Ren, T. 2013. Variation in load transfer along the length of fully encapsulated rock bolts, based on the installation mixing parameters. 13th Coal Operators' Conference, University of Wollongong. pp. 137-143.

Hoek, E., Carranza-Torres, C., and Corkum, B. 2002. Hoek-Brown failure criterion-2002 edition. In: Proceedings of the fifth North American rock mechanics symposium, Toronto, Canada. pp. 267-273.

Hsiao, F.Y., Wang, C.L., and Chern, J.C. 2009. Numerical simulation of rock deformation for support design in tunnel intersection area. Tunnelling and underground space technology 24(1): 14-21. doi:

Hyett, A.J., Moosavi, M., and Bawden, W.F. 1996. LOAD DISTRIBUTION ALONG FULLY GROUTED BOLTS, WITH EMPHASIS ON CABLE BOLT REINFORCEMENT. International Journal for Numerical and Analytical Methods in Geomechanics 20(7): 517-544.

Indraratna, B., and Kaiser, P.K. 1990. Analytical model for the design of grouted rock bolts. International Journal for Numerical and Analytical Methods in Geomechanics 14(4): 227-251.

Itasca. 2006. FLAC_fast Lagrangian analysis of continua. In Version 5. Itasca Consulting Group Inc.

Li, C., and Stillborg, B. 1999. Analytical models for rock bolts. International Journal of Rock Mechanics and Mining Sciences 36(8): 1013-1029.

Littlejohn, G.S., and Bruce, D.A. 1975. Rock anchors-state ofthe art. Design Ground Eng. Part 1, 2548.

Liu, H.Y., Small, J.C., and Carter, J.P. 2008. Full 3D modelling for effects of tunnelling on existing support systems in the Sydney region. Tunnelling and underground space technology 23(4): 399-420.

Ma, S., Nemcik, J., and Aziz, N.I. 2013. An analytical model of fully grouted rock bolts subjected to tensile load. Construction and Building Materials(Accepted).

Mark, C., Gale, W., Oyler, D., and Chen, J. 2007. Case history of the response of a longwall entry subjected to concentrated horizontal stress. International Journal of Rock Mechanics and Mining Sciences 44(2): 210-221.

Nitzsche, R.N., and Haas, C.J. 1976. Installation induced stresses for grouted roof bolts. International Journal of Rock Mechanics and Mining Sciences \& Geomechanics Abstracts 13(1): 17-24.

Osgoui, R.R., and Oreste, P. 2010. Elasto-plastic analytical model for the design of grouted bolts in a Hoek-Brown medium. International Journal for Numerical and Analytical Methods in Geomechanics 34(16): 1651-1686. 
Ren, F.F., Yang, Z.J., Chen, J.F., and Chen, W.W. 2010. An analytical analysis of the full-range behaviour of grouted rockbolts based on a tri-linear bond-slip model. Construction and Building Materials 24(3): 361-370.

Sun, X. 1984. Grouted rock bolt used in underground engineering in soft surrounding rock or in highly stressed regions. International Symposium on Rock Bolting, A. A. Balkema. pp. pp. 93-100.

Winsdor. 1997. Rock reinforcement systems. Int J Rock Mech Min Sci Geomech Abstr 34(6): 919-951.

\section{Figure captions:}

Fig. 1 Steel tubes with stalled rockbolts

Fig. 2 The $100 \mathrm{~mm}$ rockbolt tube sections

Fig. 3 The push test setup

Fig. 4 Load-displacement relationships of sections along bolt 10

Fig. 5 Bond-slip relationships of section $\mathrm{K}, \mathrm{L}$ and $\mathrm{N}$ of bolt 10

Fig. 6 Behaviour of shear coupling springs of rockbolt element (Itasca, 2006)

Fig. 7 Rockbolt elements, element numbers and node numbers

Fig. 8 Comparison of bond-slip curves for three bolt sections (K, L and N) with the input bond-slip relationship

Fig. 9 Modelled load-displacement of rockbolt 10

Fig. 10 Modelled axial force distribution along the rockbolt when $P=320 \mathrm{kN}$

Fig. 11 Modelled shear force distribution along the rockbolt when $P=320 \mathrm{kN}$

Fig. 12 Numerical model of reinforced roadway with fully grouted rockbolts.

Fig. 13 Interfacial shear force and axial force distribution along the bolts in Model 1

Fig. 14 Interfacial shear and axial forces distribution along the bolt 1 in Model 1

Fig. 15 Axial force developed in rock bolt for various face advance positions, after Gale, et al.

Fig. 16 Interfacial shear force and axial force distribution along the bolts in Model 2

Fig. 17 Interfacial shear force and axial force distribution along the bolt 1 in Model 2 
Fig. 18 The comparison of the rockbolts with plates and without plates

Fig. 19 Axial force and shear force distributions of rockbolts for Model 4 

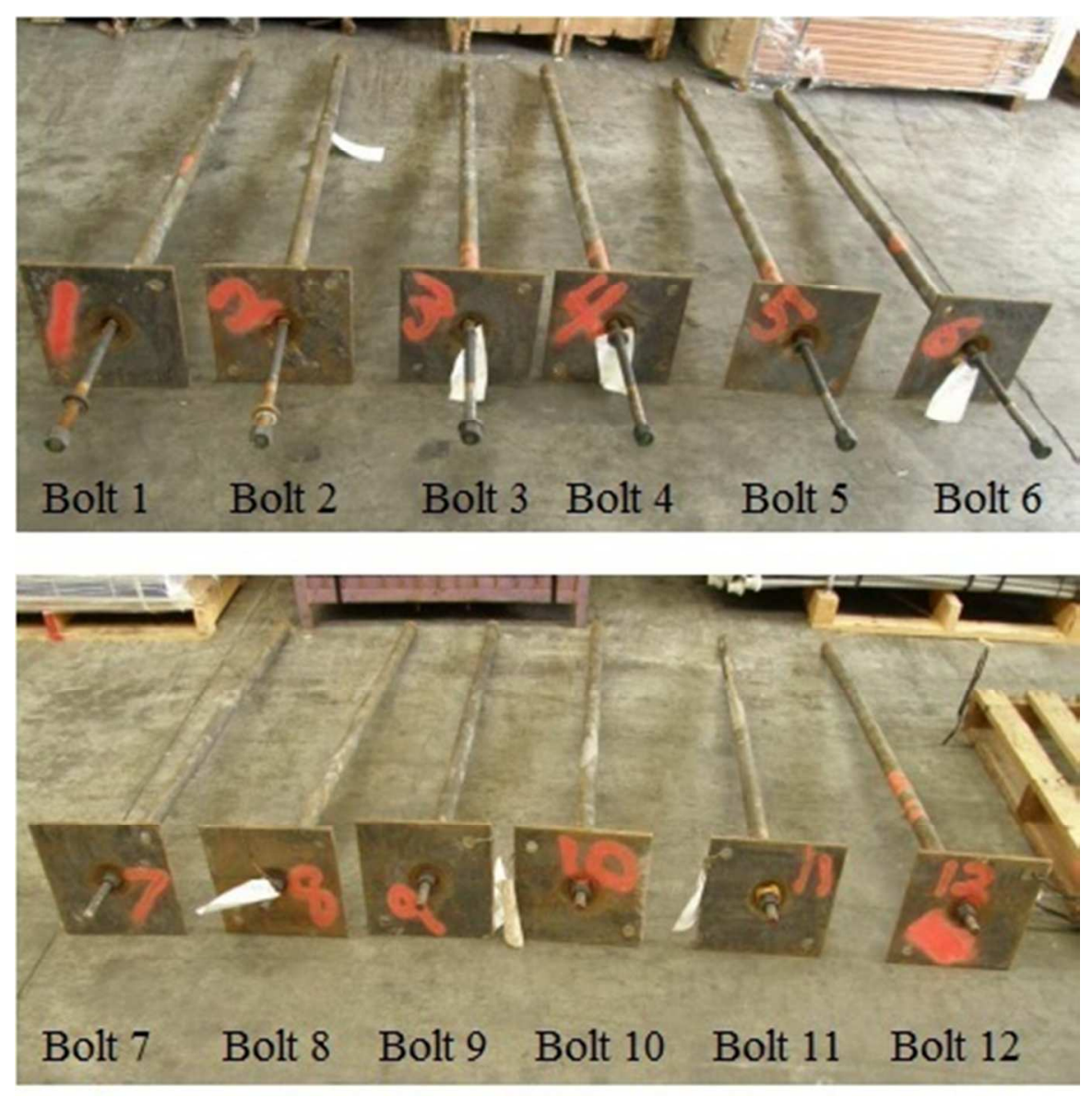

Fig. 1 Steel tubes with stalled rockbolts $117 \times 118 \mathrm{~mm}$ (96 x 96 DPI) 


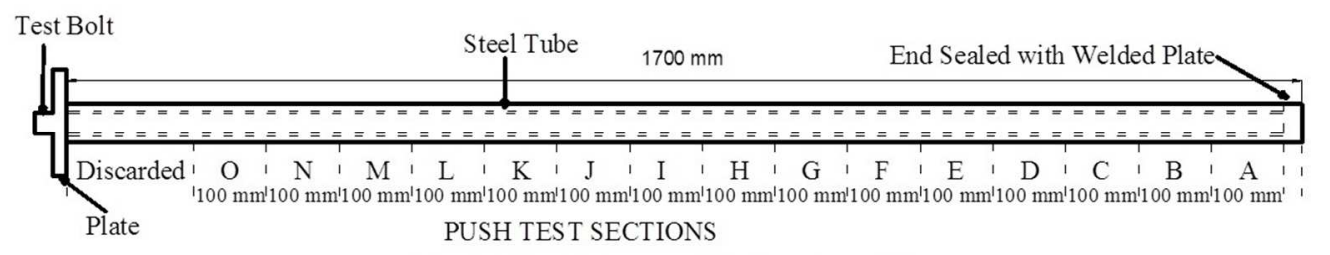

Fig. 2 The $100 \mathrm{~mm}$ rockbolt tube sections $230 \times 45 \mathrm{~mm}(127 \times 128 \mathrm{DPI})$ 


\section{Page 23 of 39}

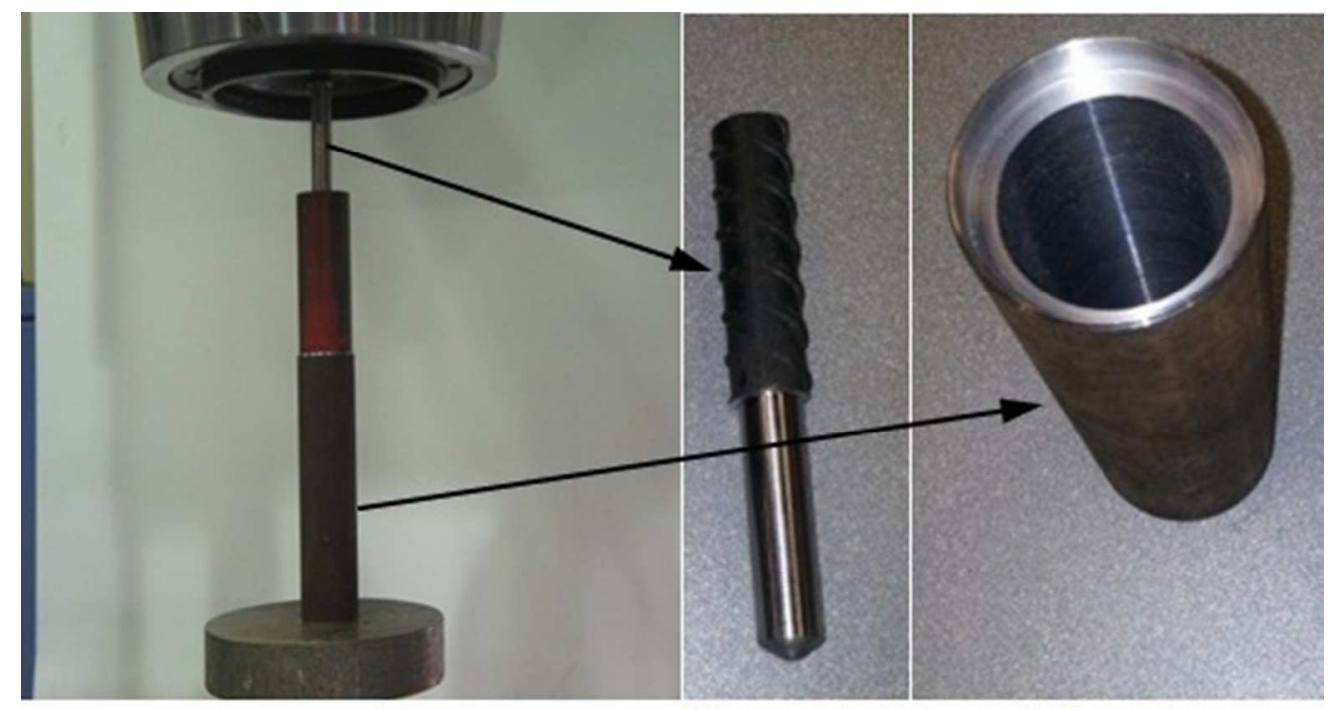

Fig. 3 The push test setup $141 \times 76 \mathrm{~mm}$ (96 x 96 DPI)

¿ुँ 


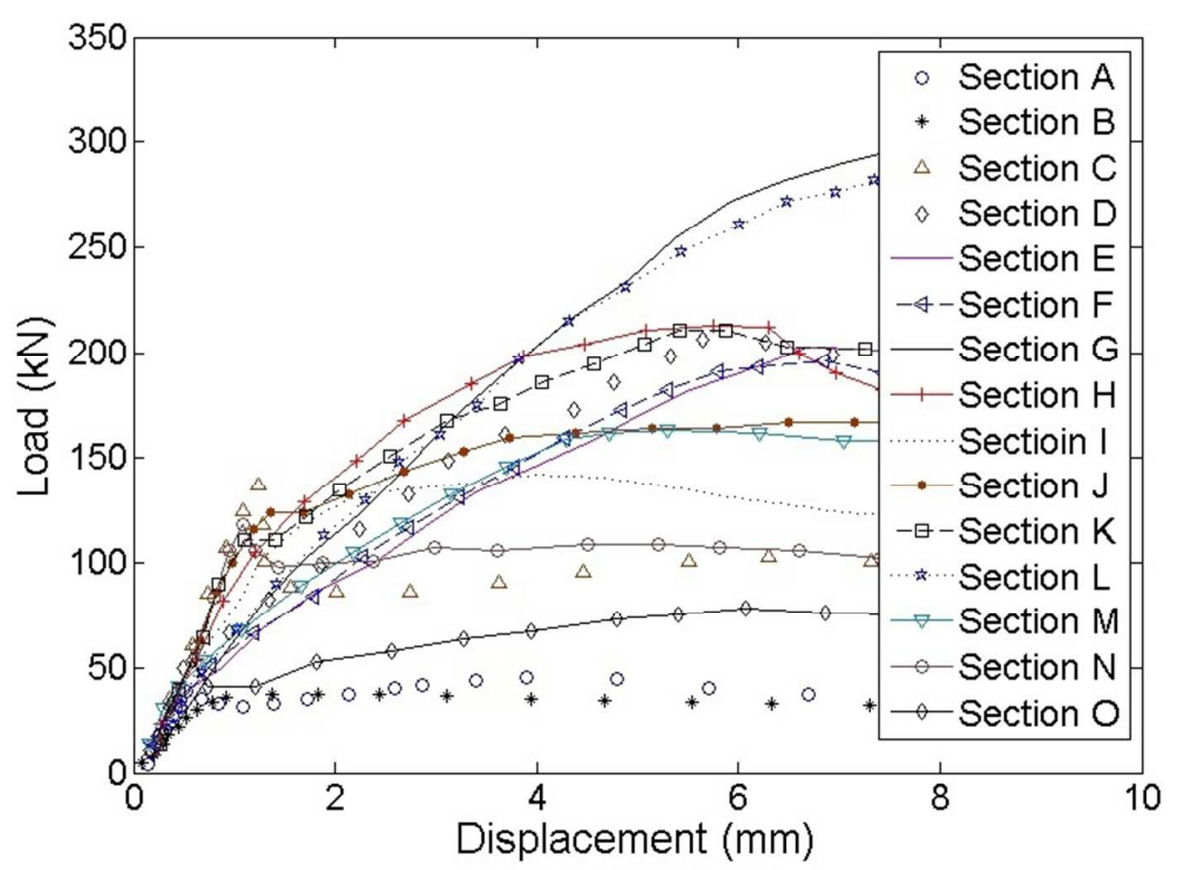

Fig. 4 Load-displacement relationships of sections along bolt 10 $224 \times 155 \mathrm{~mm}$ (96 x 96 DPI) 


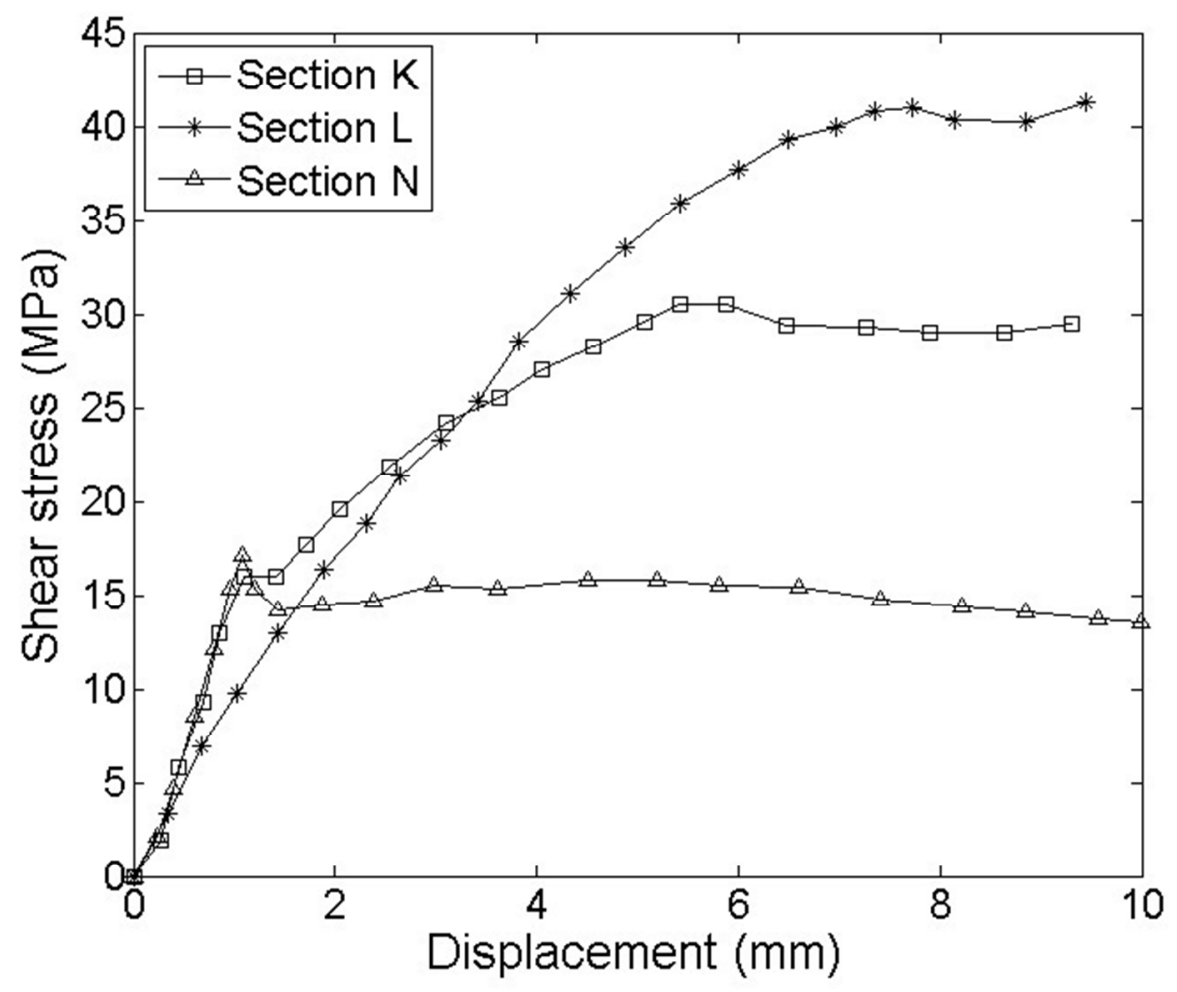

Fig. 5 Bond-slip relationships of section $\mathrm{K}, \mathrm{L}$ and $\mathrm{N}$ of bolt 10 $194 \times 155 \mathrm{~mm}(96 \times 96 \mathrm{DPI})$ 


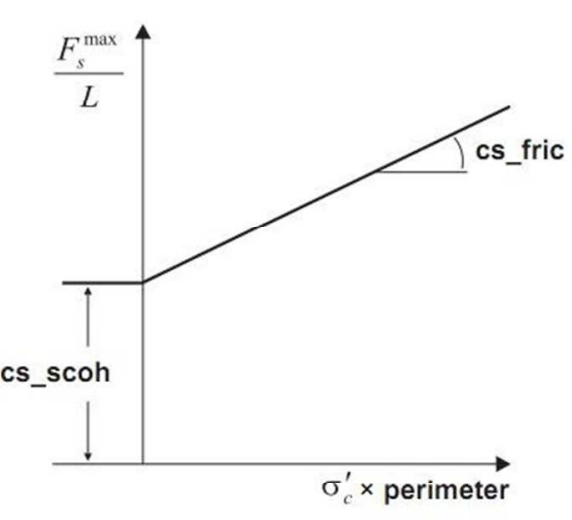

a) Shear strength criterion

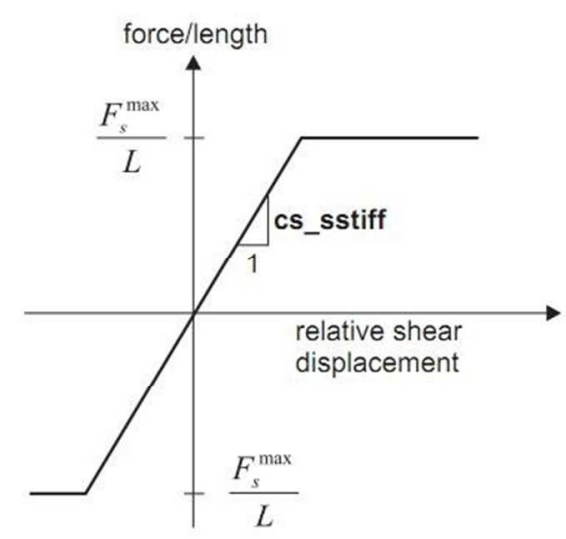

b) Shear force versus displacement

Fig. 6 Behaviour of shear coupling springs of rockbolt element (Itasca, 2006) $230 \times 113 \mathrm{~mm}(96 \times 96 \mathrm{DPI})$ 


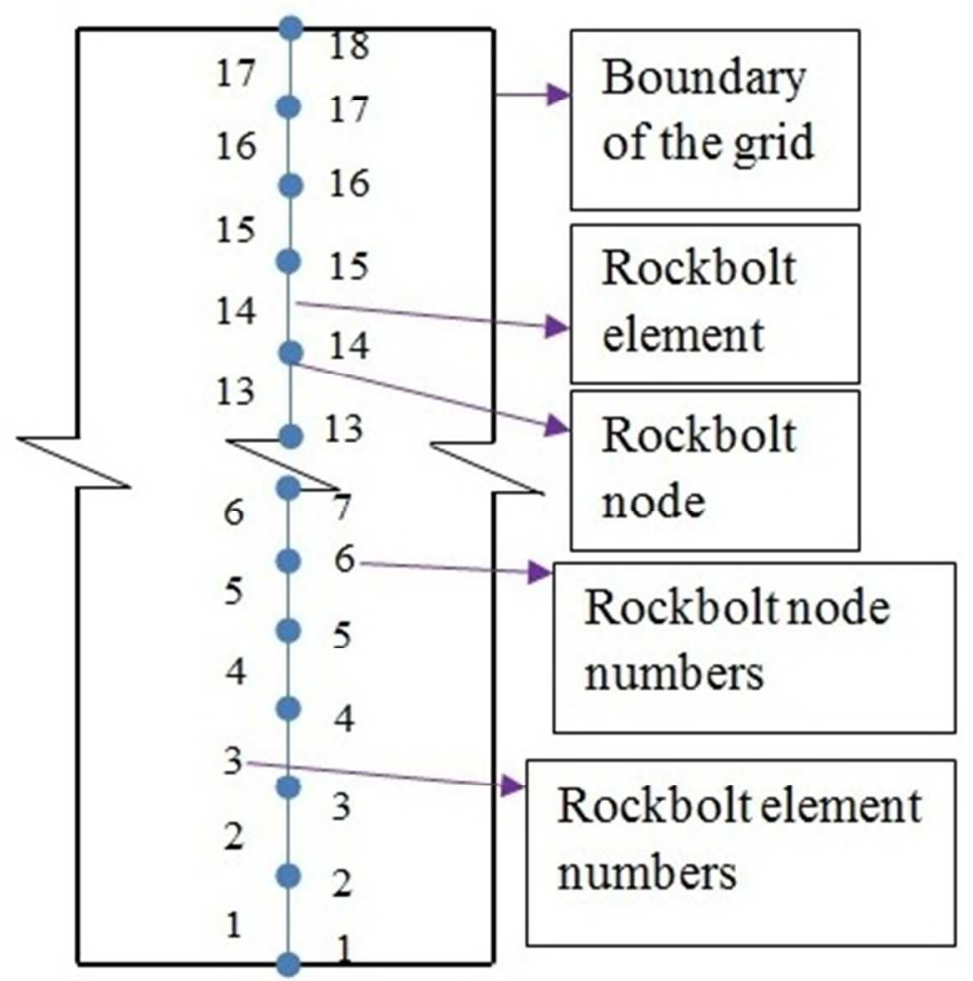

Fig. 7 Rockbolt elements, element numbers and node numbers $139 \times 117 \mathrm{~mm}$ (96 x 96 DPI) 


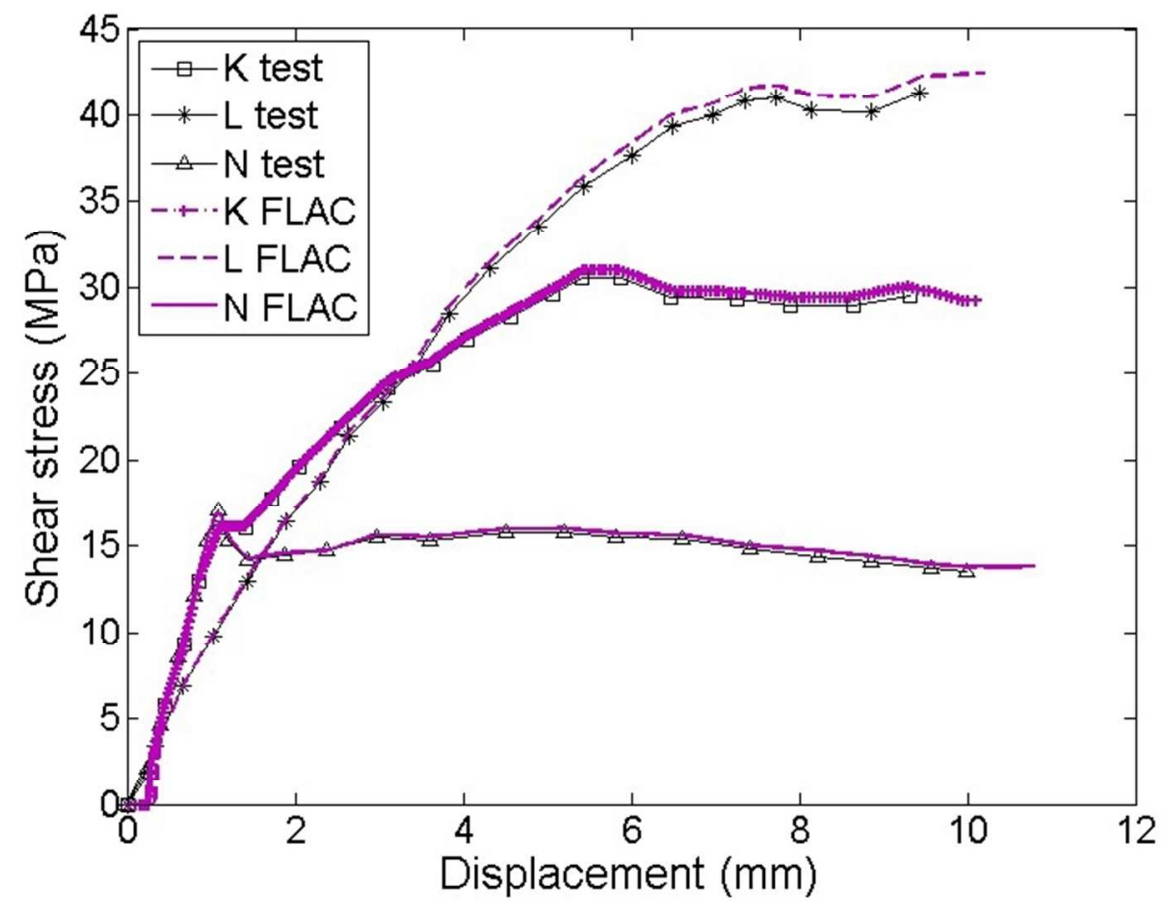

Fig. 8 Comparison of bond-slip curves for three bolt sections ( $K, L$ and $N)$ with the input bond-slip relationship $213 \times 157 m m$ (96 x 96 DPI) 


\section{Page 29 of 39}

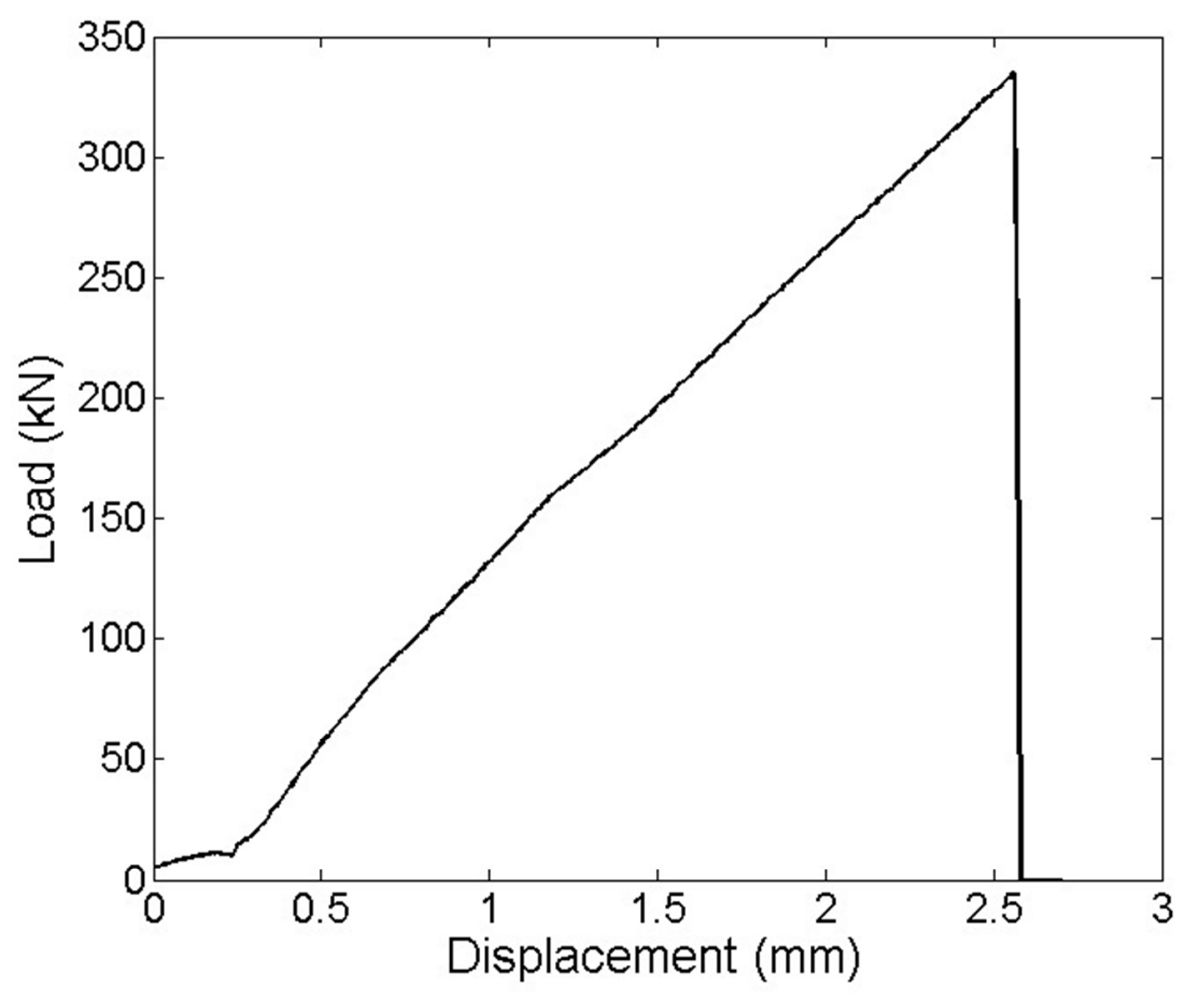

Fig. 9 Modelled load-displacement of rockbolt 10 $194 \times 155 \mathrm{~mm}$ (96 x 96 DPI) 
Boundary plot Rockbolt Plot Axial Force on Structure Max. Value \#1 (Rockb) -4.283E+03 \#2 (Rockb) -1.074E+04 \#3 (Rockb) -1.076E+04 \# 4 (Rockb) -1.177E+04 \# 5 (Rockb) -1.175E+04 \#6 (Rockb) -1.940E+04 \# 7 (Rockb) -2.31OE+04 \#8 (Rockb) -2.310E+04 \# 9 (Rockb) -3.830E+04 \#10 (Rockb) -6.185E+04 \#11 (Rockb) -9.439E+04 \#12 (Rockb) -1.311E+O5 \#13 (Rockb) -1.835E+05 \#14 (Rockb) -2.841E+05 \#15 (Rockb) -3.267E+05 \#16 (Rockb) -3.267E+05 \#17 (Rockb) -3.267E+05

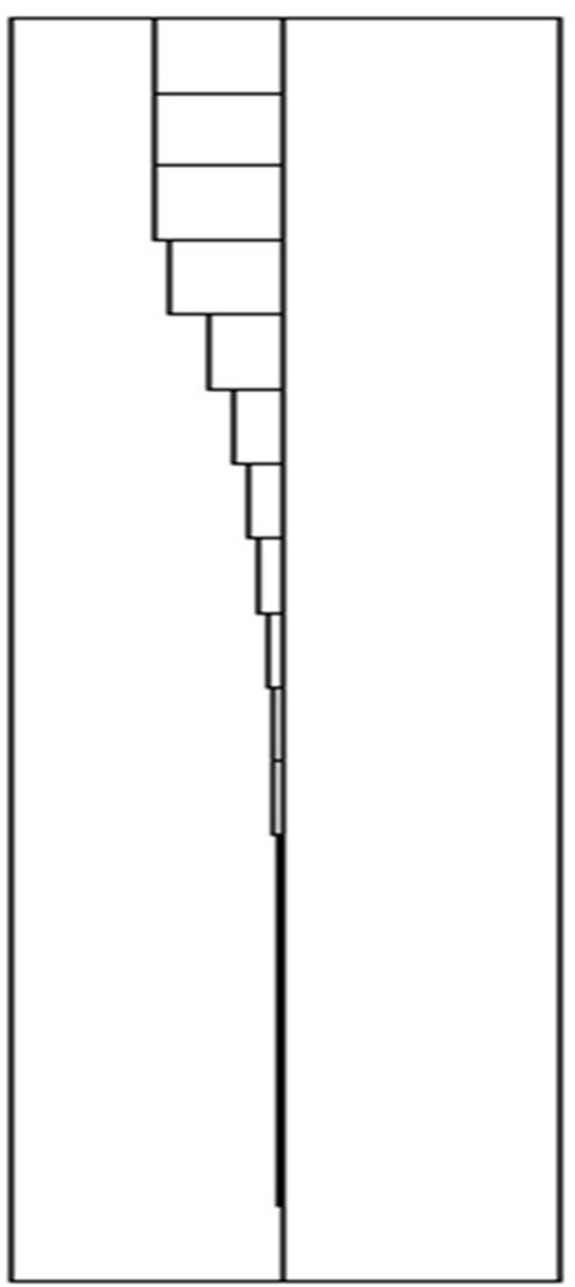

Fig. 10 Modelled axial force distribution along the rockbolt when $P=320 \mathrm{kN}$ 202×199mm (96 x 96 DPI) 
Boundary plot Rockbolt Plot Sp.Shear Fc on Structure Max. Value

\#1 (Rockb)

\# 2 (Rockb)

\# 3 (Rockb)

\# 4 (Rockb)

\# 5 (Rockb)

\# 6 (Rockb)

\#7 (Rockb)

\#8 (Rockb)

\# 9 (Rockb)

\#10 (Rockb)

\#11 (Rockb)

6. $446 E+03$

$6.446 E+03$

$1.027 E+03$

$1.027 E+03$

$7.646 E+03$

$7.646 E+03$

$3.676 E+03$

$1.517 E+04$

2.351E+04

$3.255 E+04$

$3.663 E+04$

$5.239 E+04$

1.006E+0S

1.006E+0S

4.249E+O4

O.OOOE+OO

\#16 (Rockb)

O.OOOE+OO

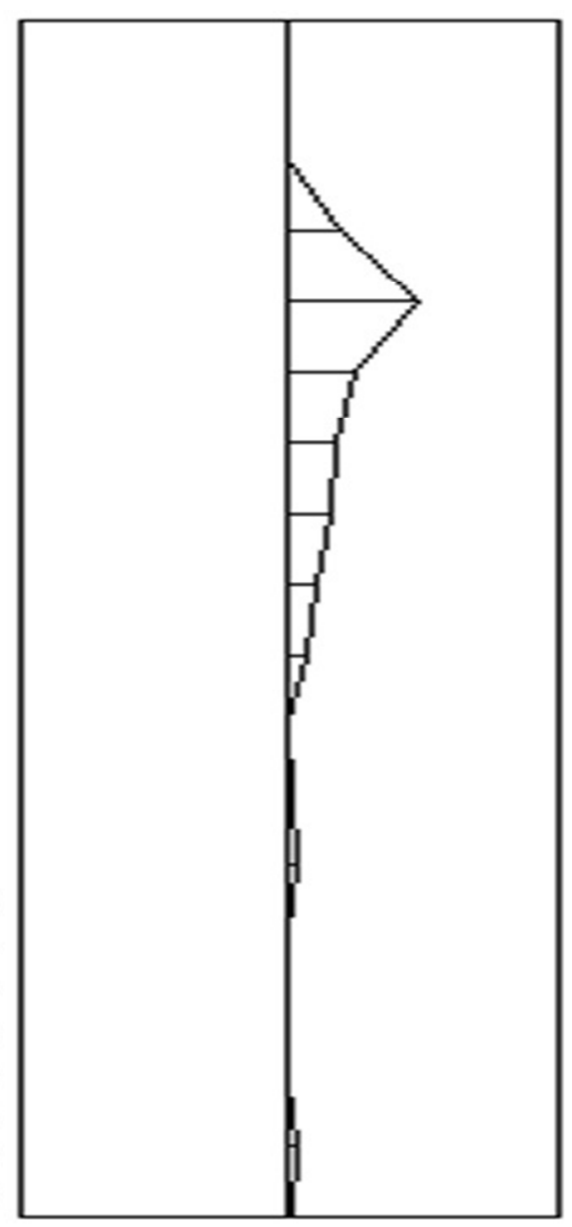

Fig. 11 Modelled shear force distribution along the rockbolt when $\mathrm{P}=320 \mathrm{kN}$ $206 \times 194 \mathrm{~mm}(96 \times 96 \mathrm{DPI})$ 


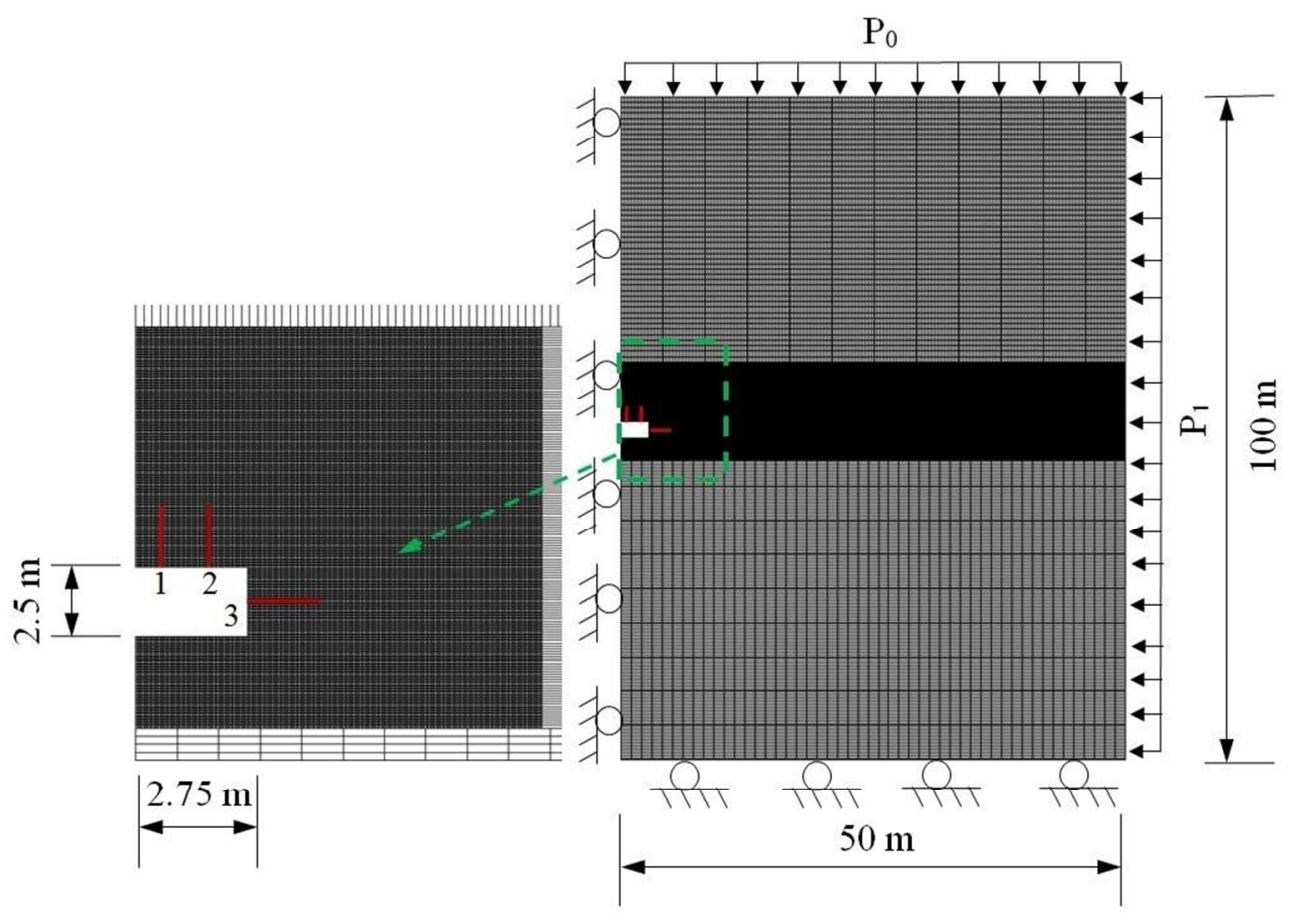

Fig. 12 Numerical model of reinforced roadway with fully grouted rockbolts. $270 \times 189 \mathrm{~mm}(96 \times 96 \mathrm{DPI})$ 


\section{Page 33 of 39}

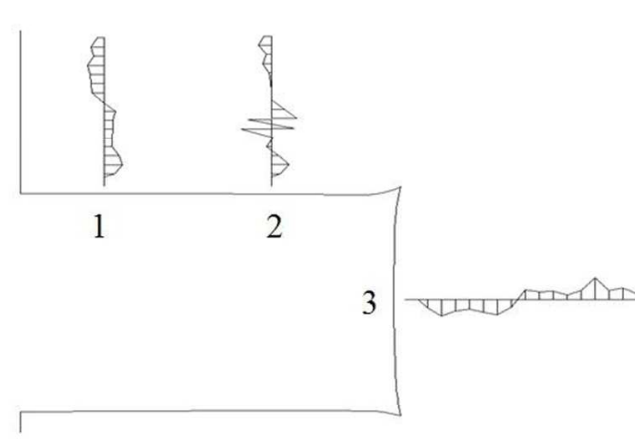

(a) Shear force distribution

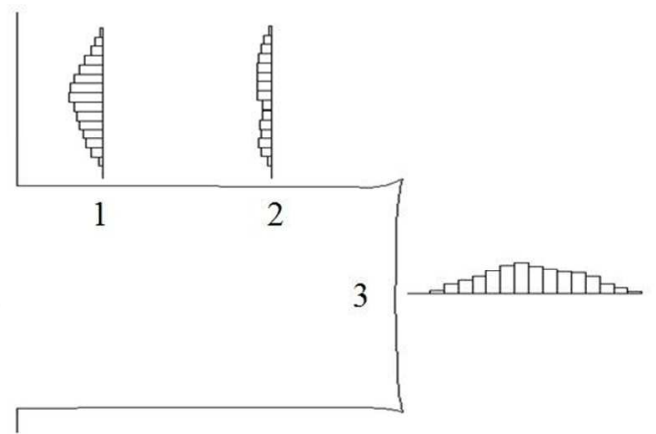

(b) Axial force distribution

Fig. 13 Interfacial shear force and axial force distribution along the bolts in Model 1 $282 \times 115 \mathrm{~mm}(96 \times 96$ DPI) 


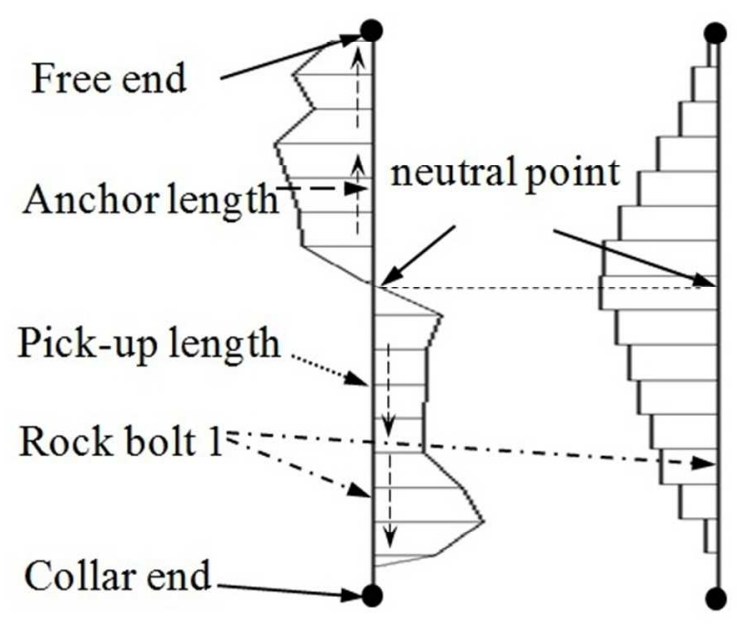

(a) Shear force distribution (b) Axial force distribution

Fig. 14 Interfacial shear and axial forces distribution along the bolt 1 in Model 1 $222 \times 146 \mathrm{~mm}(96 \times 96 \mathrm{DPI})$ 


\section{Page 35 of 39}

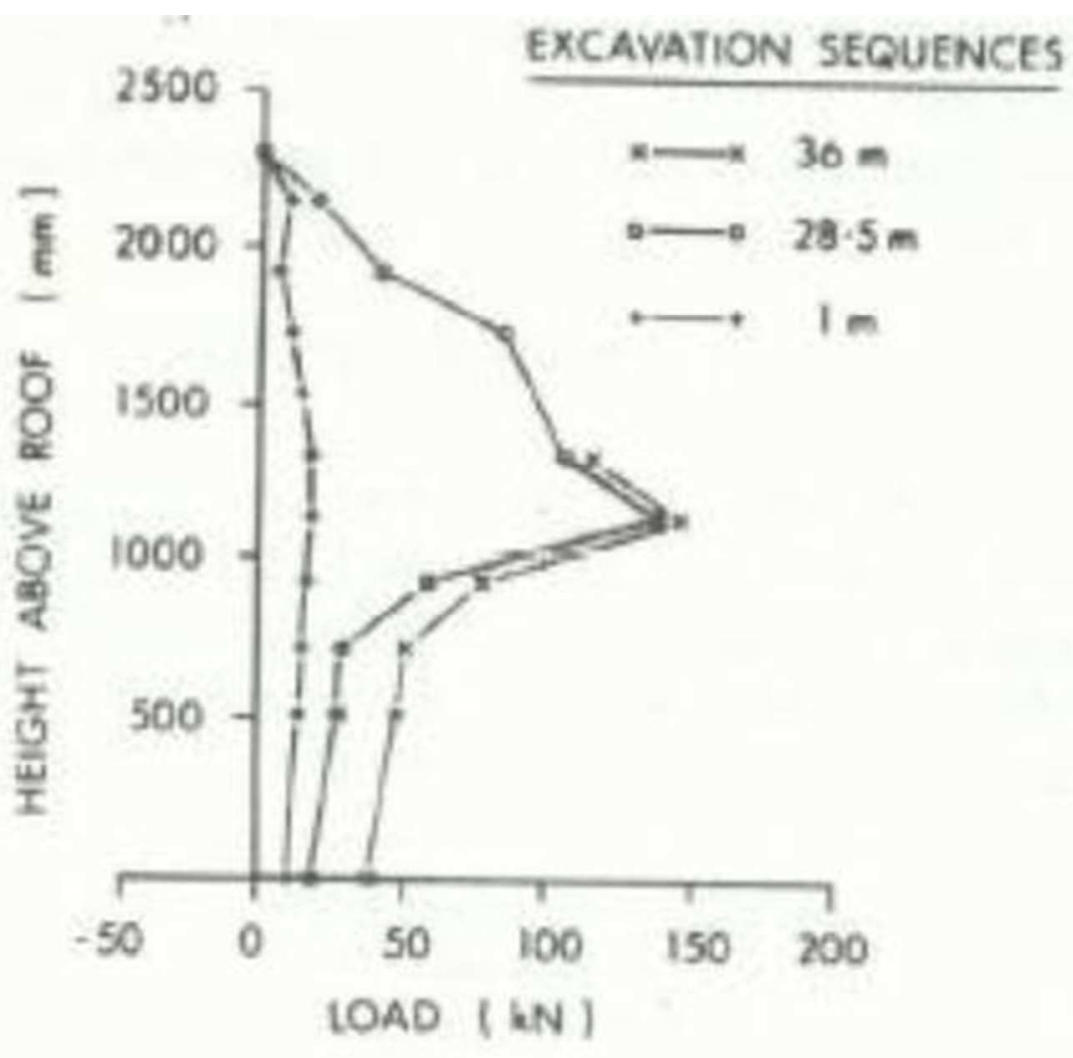

Fig. 15 Axial force developed in rock bolt for various face advance positions, after Gale, et al. (1992) $115 \times 106 \mathrm{~mm}(96 \times 96 \mathrm{DPI})$ 


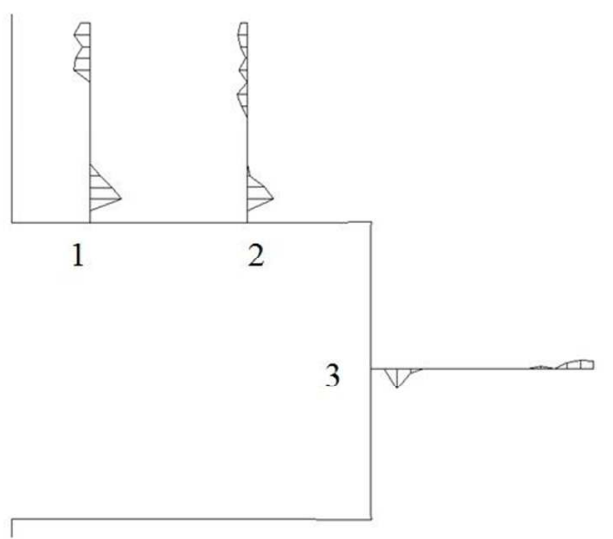

(a) Shear force distribution

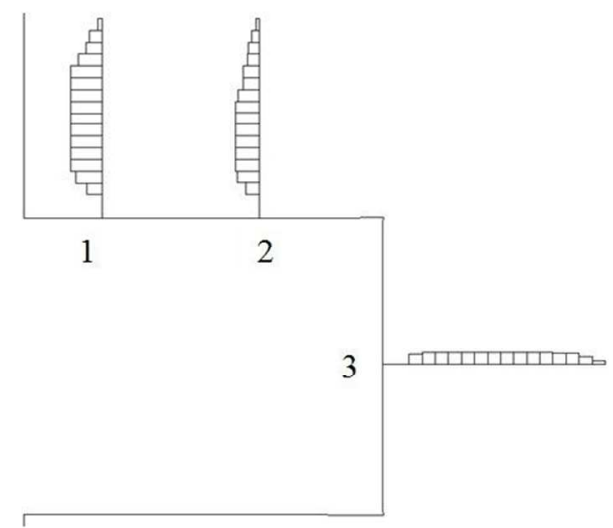

(b) Axial force distribution

Fig. 16 Interfacial shear force and axial force distribution along the bolts in Model 2 $278 \times 136 \mathrm{~mm}(96 \times 96 \mathrm{DPI})$ 


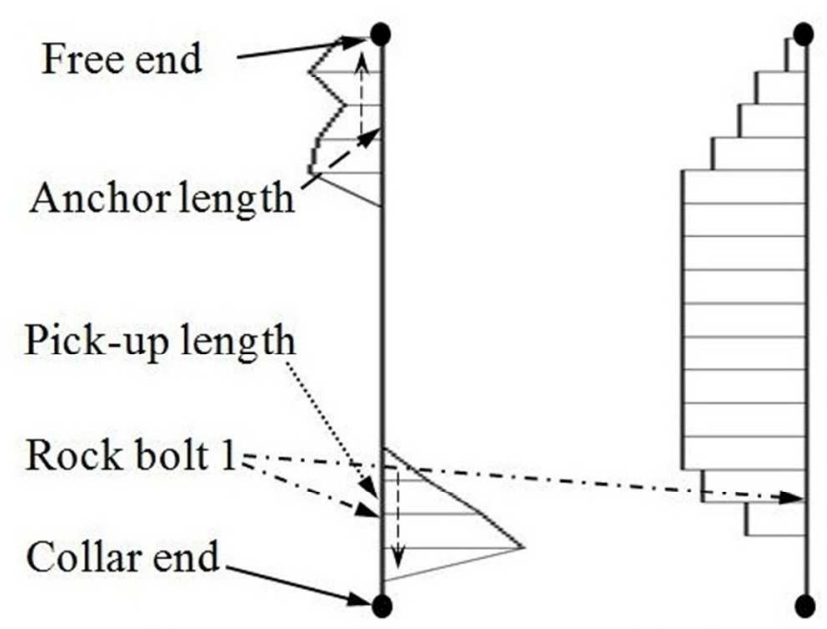

(a) Shear force distribution (b) Axial force distribution

Fig. 17 Interfacial shear force and axial force distribution along the bolt 1 in Model 2 $215 \times 137 \mathrm{~mm}(96 \times 96 \mathrm{DPI})$ 


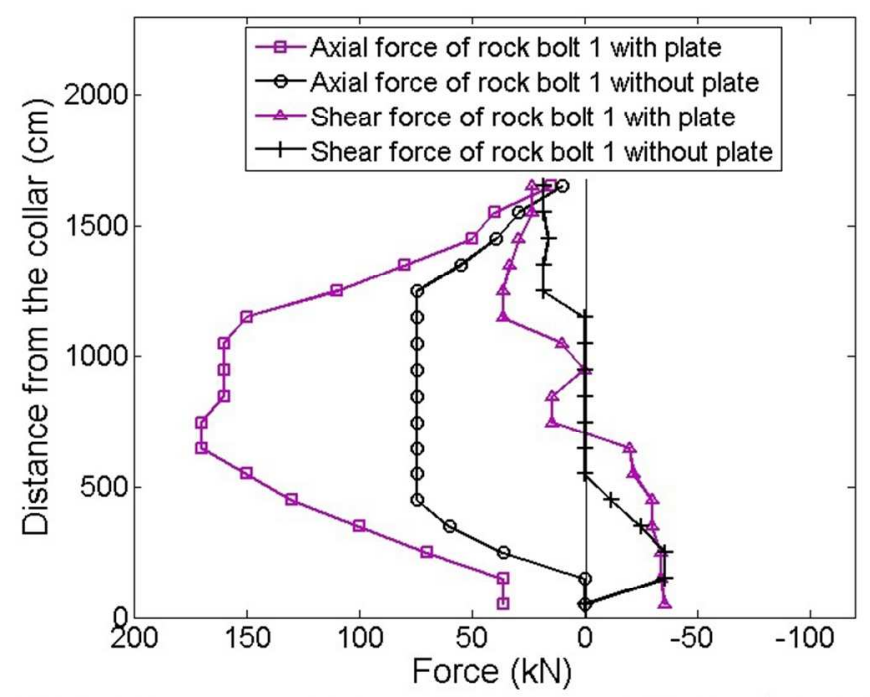

(a) FLAC result comparison of rockbolt 1 in Model 2 and Model 3

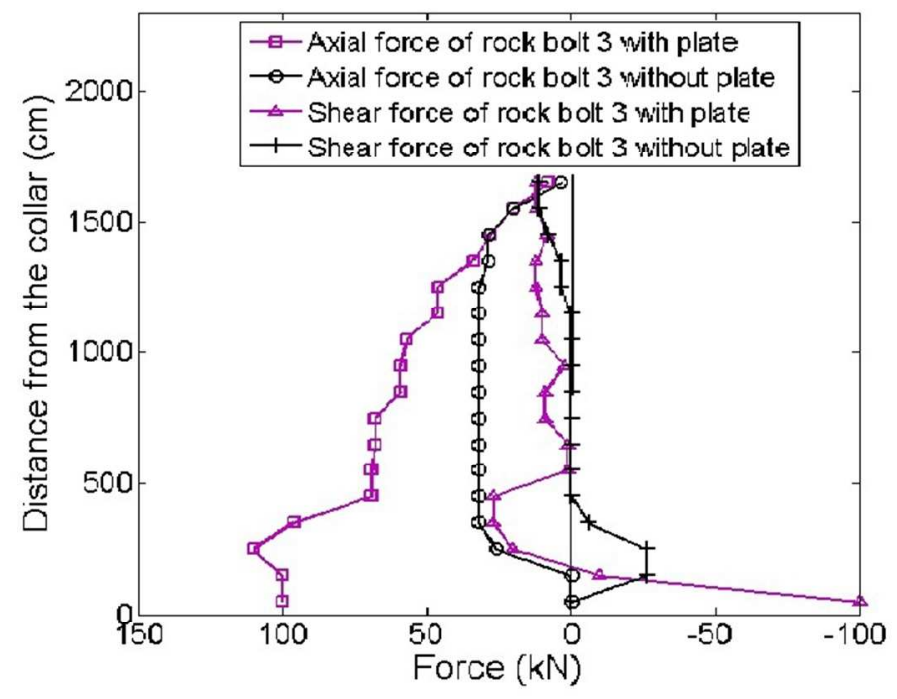

(b) FLAC result comparison of rockbolt 3 in Model 2 and Model 3

Fig.18 The comparison of the rockbolts with plates and without plates $224 \times 330 \mathrm{~mm}(96 \times 96 \mathrm{DPI})$ 


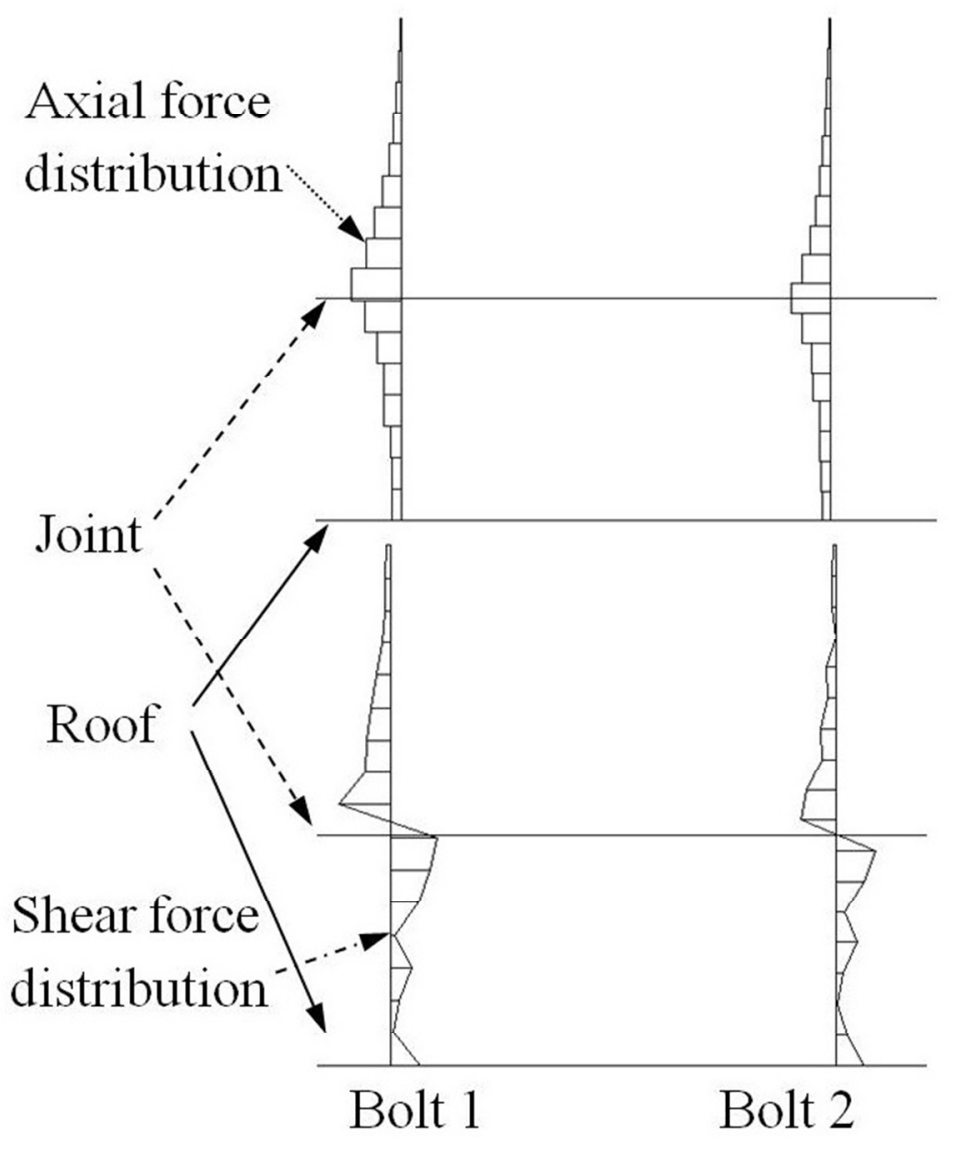

Fig. 19 Axial force and shear force distributions of rockbolts for Model 4 $241 \times 218 \mathrm{~mm}(96 \times 96$ DPI) 